\title{
Oral Submucous Fibrosis: Review on Etiopathogenesis
}

\section{Sunita N Dyavanagoudar*}

Department of Oral Pathology, Sri Hassanamba Dental College and Hospital, Vidyanagar, Hassan, Karnataka, India

\begin{abstract}
Summary data from recent epidemiological studies provide overwhelming evidence that areca nut is the main aetiological factor for OSF. Commercially freeze dried products such as pan masala, Guthka and mawa have high concentrates of areca nut per chew and appear to cause OSF more rapidly than by self prepared conventional betel quid that contain smaller amounts of areca nut. It is logical to hypothesize that the increased collagen synthesis or reduced collagen degradation as possible mechanisms in the development of the disease. These chemicals appear to interfere with the molecular processes of deposition and/or degradation of extracellular matrix molecules such as collagen. In vitro studies on human fibroblasts using areca extracts or chemically purified arecoline support the theory of fibroblastic proliferation and increased collagen formation that is also demonstrable histologically in human OSF tissues. The copper content of areca nut is high and the possible role of copper as a mediator of fibrosis is supported by the demonstration of up regulation of lysyl oxidase in OSF biopsies. It has been postulated that areca nut may also induce the development of the disease by increased levels of cytokines in the lamina propria. Current evidence implicates collagen-related genes in the susceptibility and pathogenesis of OSF. The individual mechanisms operating at various stages of the disease-initial, intermediate and advanced-need further study in order to propose appropriate therapeutic interventions.
\end{abstract}

Keywords: Oral Submucous fibrosis (OSF); Arecanut; Arecoline; Arecadine; TGF $\beta$; Basis fibroblsatic growth factor

\section{Introduction}

Oral submucous fibrosis (OSF) is a high risk precancerous condition which was first described in the early 1950s characterized by changes in the connective tissue fibers of the lamina propria and deeper parts leading to stiffness of the mucosa and restricted mouth opening seen predominantly in people of Asian descent. The disease is predominantly seen in India, Bangladesh, Sri Lanka, Pakistan, Taiwan, China and among other Asiatics, with a reported prevalence ranging up to $0.4 \%$ in Indian rural population (Murti et al., 1995). Epidemiological and in vitro experimental studies have shown that chewing areca nut (Areca catechu) is the major aetiological factor for OSF (Caniff and Harvey, 1981). Although there are regional variations in the type of areca nut products used in India, the betel quid (BQ) was the most popular and prevalent habit in ancient Indian culture. But in 1980, both areca quid products such as Pan masala (Areca quid) and Gutkha (AQ tobacco) were introduced in Indian market as commercial preparations. Since then there has been an increase in the use Pan Masala (Areca quid) and Gutkha (AQ + $\mathrm{T})$ in the younger age groups, which had lead to increased incidence of OSF (Gupta et al., 1998). Pan Masala (Areca quid) includes areca nut, catechu, lime, flavours and spices. Our previous hospital-based case-control study has proved strong association of Pan Masala (AQ) with highest relative risk (489.1) of development of OSF (Hazare et al. 1998). Gutkha (AQ + T) contains all ingredients of Pan Masala (AQ) plus tobacco and other contents, that are closely guarded secretes and is a commercial substitute to local preparation popularly known as Kharra/ Mawa (Sinor et al., 1990). The rapidly increasing prevalence of this habit can be judged from the reports that the Indian market for Pan masala (AQ) and Guthka (AQ + T) is worth 25 billion (US\$ 500 million) (Gupta and Ray, 2004). When the disease was first described it was classified as an idiopathic disorder (Schwartz, 1952).

\section{Mortality/morbidity}

OSMF has a high rate of morbidity because is causes a progressive inability to open the mouth, resulting in eating and consequent nutritional deficiencies. OSMF also has a significant mor-

- Progressive inability to open the mouth (trismus) due to oral fibrosis and scarring

- Oral pain and a burning sensation upon consumption of spicy foodstuffs

- Increased salivation

- Change of gustatory sensation

- Hearing loss due to stenosis of the eustachian tubes

- Dryness of the mouth

- Nasal tonality to the voice

- Dysphagia to solids (if the esophagus is involved)

- Impaired mouth movements (eg, eating, whistling, blowing, sucking)

- Laboratory findings:

- Decreased hemoglobin levels

- Decreased iron levels

- Decreased protein levels

- Increased erythrocyte sedimentation rate

- Decreased vitamin B complex levels

Table 1: Symptoms and signs of oral submucous fibrosis.

*Corresponding author: Dr Sunita N Dyavanagoudar, Basav Nivas, Jayanagar, Dharwad, Karnataka, India, Tel: 91-9742366645; E-mail: drsunitad@yahoo.com

Received November 16, 2009; Accepted December 16, 2009; Published December 21, 2009

Citation: Dyavanagoudar SN (2009) Oral Submucous Fibrosis: Review on Etiopathogenesis. J Cancer Sci Ther 1: 072-077. doi:10.4172/19485956.1000011

Copyright: (c) 2009 Dyavanagoudar SN. This is an open-access article distributed under the terms of the Creative Commons Attribution License,which permits unrestricted use, distribution, and reproduction in any medium, provided the original author and source are credited. 
tality rate because of it can transform into oral cancer, particularly squamous cell carcinoma, at a rate of $7.6 \%$. Signs and symptoms of OSF are mentioned in Table 1.

\section{Pathogenesis}

The role of the constituents of areca nut in the pathogenesis of OSF has been studied in detail over last two decades. It is apparent that fibrosis and hyalinization of subepthelial tissues account for most of the clinical features encountered in this condition. Moreover, substantial amount of research on elucidating the etiology and pathogenesis appear to have been focused on changes in the extracellular matrix (ECM). It is logical to hypothesize that the increased collagen synthesis or reduced collagen degradation as possible mechanisms in the development of the disease. There are numerous biological pathways involved in the above processes and, it is likely that the normal regulatory mechanisms are either down regulated or up regulated at different stages of the disease (Figure 1 and Figure 2).

Quid has been defined as a substance or mixture of substances placed in the mouth or chewed and remaining in contact with the mucosa usually containing one or both of the two basic ingredi-

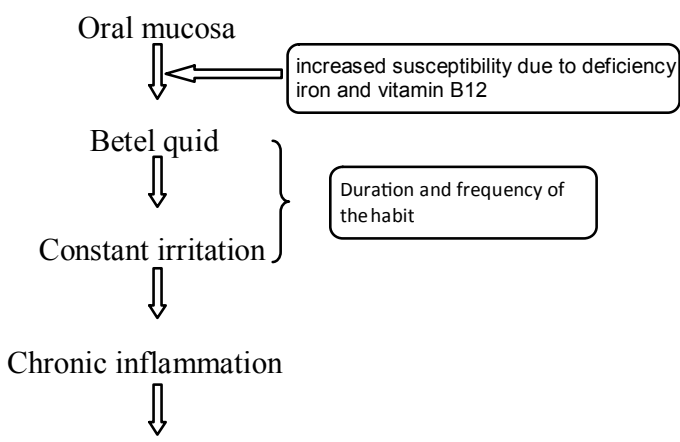

Activated $\mathrm{T}$ cell and macrophages at the site $\sqrt{ }$

Increase in cytokines IL $6, \mathrm{TNF}$, IF $\alpha$, increase in growth factor TGF $\beta$

Figure 1: Initial events of the disease process oral mucosa which is in direct contact with the betel quid due to the habit, is the site of constant irritation (Rajalalitha and Vali, 2005).

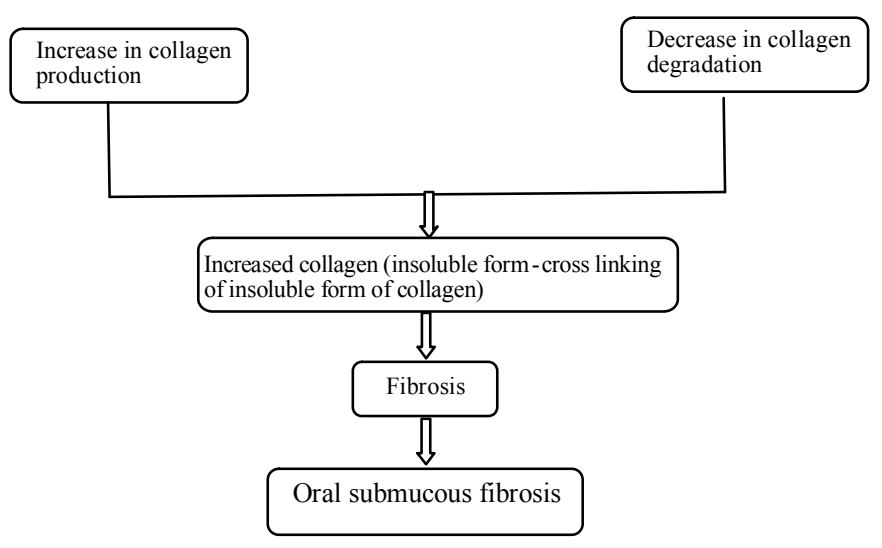

Figure 2: Overall effect of activated TGF beta pathway. There is in increase $n$ collagen production and cross linking (insoluble form) along with the decrease in the collagen degradation. This produces increased collagen deposition in the subepithelial connective tissue layer of the oral mucosa leading to OSF ents tobacco and/or areca nut in raw or any manufactured or processed form (Zain et al., 1999). The major areca nut alkaloids are arecoline, arecadine, arecolidine, guyacoline and guacine (IARC anonymous, 1985). The important flavonoid components in areca nut are tannins and catechins. These alkaloids undergo nitrosation and give rise to $\mathrm{N}$-nitrosamine which might have cytotoxic effect on cells (Hoffmann et al., 1994).

The betel quid is placed in the buccal vestibule for about 15 minutes to an hour and repeated 5 to 6 times a day which leads to constant contact between the mixture and oral mucosa. The alkaloids from the quid are absorbed into the mucosa and undergoes metabolism. Microtrauma produced by the friction of coarse fibers of areca nut also facilitates diffusion of the alkaloids into the subepithelial connective tissue resulting in juxtaepitheial inflammatory cell infiltration (Chiang et al., 2002).

Oral submucous fibrosis (OSF) is widely considered to be a potent precancerous condition whose predominant characteristics are the excessive and abnormal deposition of extracellular matrix (ECM) components that may affect adversely the routine oral functions. From a clinico-pathologic point of view, fibrosis may be considered as a somewhat irreversible state of tissue alteration, during which resolution of the healing process fails to occur. Increasingly, it has become appreciated that certain of these actions of ECM derive from its ability to sequester and modulate the activity of specific growth factors (Nathan and Sporn, 1991). Of all of the growth factors, none has been found to have the diversity of effects on ECM ascribed to transforming growth factor- $\beta$ (TGF- $\beta$ ). This peptide plays a critical role not only in synthesis and degradation of ECM but also in response of cells to ECM mediated through integrin receptors; moreover, specific components of the ECM, in turn, can both deliver TGF$\beta$ and regulate its activity (Roberts et al., 1988; Roberts et al., 1990).

The molecular events in the pathogenesis of OSF discussed by a 29. Rajalalitha and Vali, (2005): collagen production pathway and collagen degradation as regulated by TGF $\beta$ and the flavonoids present in areca nut.

\section{Collagen production pathway}

There are three main events in this pathway activation of procollagen, elevation of procollagen proteinase levels, and upregulation of lysyl oxidase (LOX activity).

Collagen is the most abundant protein in the human body and plays an important role in the structural element of connective tissue. They are triple helix stabilized by unusual crosslink. The processing of fibrillar collagen occurs in a stepwise manner. Procollagen genes are transcribed and translated to form procollagen monomeric chains. The genes COL1A2, COL3A1, COL6A1, COL6A3, COL7A1 have been identified as definitive TGF- $\beta$ targets (Rajalalitha and Vali, 2005). The activation of collagen I and VII collagen gene expression by TGF- $\beta$ has been demonstrated. The activation of procollagen genes by TGF$\beta$ is causing an increased expression of procollagen genes and hence increases collagen level in OSF. Elevation of procollagen proteinases such as PCP that cleaves C-terminal and PNP's (PNP1 and PNP 2) cleaves $\mathrm{N}$ terminal play essential role in pathogenesis of OSF. Thus, TGF-b may play an important role in inducing fibrotic tissue formation, while connective tissue growth fac- 


\section{Journal of Cancer Science \& Therapy - Open Access}

JCST/Vol.1 Issue 2

tor (CTGF) is important in maintaining fibrosis. In the study conducted by Yi-Ting et al., (2009) found arecoline stimulated CTGF production in buccal mucosal fibroblasts (BMF). BMFs could contribute to the pathogenesis of OSF by producing CTGF during arecanut chewing. OSF could be driven by a wave of increased CTGF synthesis during arecanut chewing, accompanied by an increased local TGF-b concentration due to inflammation regularly found in OSF. Recent study has shown that curcumin (1,7-bis(4-hydroxy-3 methoxyphenyl)-1,6-heptadiene3,5 -dione), the major yellow pigment in turmeric, curry and mustard, has high antioxidant and anti inflammatory activity and is widely used as a flavoring and coloring agent in foods and as an herbal medicine to treat chronic inflammatory diseases (Goel et al., 2008) suppresses the expression of extracellular matrix expression through suppressing ERK and NF-jB signalling. Interestingly, researchers found curcumin could completely inhibit dependent (Chen and Zheng, 2008).

\section{Up-regulation of LOX}

The copper content of areca nut is high and the levels of soluble copper in saliva may rise in volunteers who chew arecaquid (Trivedy et al., 1997). The same group showed that the oral mucosa of areca nut chewers had significantly raised levels of copper when compared with the control subjects (Trivedy et al., 2000). The association between copper and OSF has been linked on the basis that excess copper is found in tissues of other fibrotic disorders- Wilson's disease, Indian childhood cirrhosis and primary biliary cirrhosis. The enzyme lysyl oxidase is found to be upregulated in OSF (Trivedy et al., 1999). This is a copper dependent enzyme (Kagen and Trackenman, 1991) and plays a key role in collagen synthesis and its cross linkage. The possible role of copper as a mediator of fibrosis is supported by the demonstration of up regulation of this enzyme in OSF biopsies (Trivedy et al., 1999) and in OSF fibroblasts compared to normal fibroblasts grown in culture (Ma et al., 1995). Copper added at various concentrations in vitro has also been shown to increase proliferation of fibroblasts in culture (Trivedy et al., 2001). The fibroblasts in OSF have not only increased lysyl oxidase activities but also specific growth characteristics. This was evident with the reported cell doubling time of 3.2 days for OSF and 3.6 days for normal fibroblasts (Ma et al., 1995). Further, OSF fibroblasts grew more rapidly than normal as the former became confluent in 5 days compared to 6 days for the latter. However, another study based on ultrasound investigations of visceral organs in OSF patients reported that there was no evidence of fibrotic changes elsewhere. Faecal copper was also normal suggesting that the copper levels were within the tolerance levels (Rajendran et al., 2003). As the oral mucosa is directly exposed to the copper challenge in chewers its effect may well be local. These different growth characteristics may either be due to the direct effects of ingredients of areca nut or secondary to inflammatory factors mediated by areca nut such as IL-1, TGF- $\beta$, IGF, EG (Haque et al., 2000). The LOX activity is important of insoluble collagen due to cross linking. The process of cross linking gives tensile strength and mechanical properties to the fibers as well as makes the collagen fibers resistant to proteolysis tilting the balance towards a fibrotic condition as present in OSF. genes in activated hepatic stellate cells by inhibiting CTGF gene arecoline-induced CTGF synthesis and the inhibition is dose-

\section{Collagen degradation pathway}

There are two main events modulated by TGF which decreases the collagen degradation, activation of inhibitor of matrix metalloproteinase gene TIMPs and activation of plasminogen activator inhibitor PAI gene.

\section{Upregulation of cyclo-oxygenase}

\section{(COX-2)}

It is known that OSF is associated with inflammatory changes in at least some stages of the disease. Prostaglandin is one of the main inflammatory mediators and its production is controlled by various enzymes such as cyclo-oxygenase (COX). Biopsies from buccal mucosa of OSF cases and from controls were stained for COX-2 by immune histochemistry and revealed that there was increased expression of the enzyme in moderate fibrosis and this disappeared in advanced fibrosis. This finding is compatible with the histology of the disease as there is lack of inflammation in the advanced disease. The above finding was confirmed by treating buccal mucosal fibroblasts with $80 \mu \mathrm{g} / \mathrm{ml}$ arecoline in culture and revealed that COX-2 expression was up-regulated as early as half an hour, indicating this to be an early cellular response to arecoline at transcriptional level. COX2 expression started to decrease when the arecoline concentration was increased upto $160 \mu \mathrm{g} / \mathrm{ml}$, and this may be due to cytotoxicity. Similar data have been reported in another study quoting 1.4-3.4-fold increase of PGE 2 production and 1.1-1.7-fold increase of $\mathrm{PGE}_{1 \alpha}$ when gingival keratinocytes were exposed to areca nut extracts (Jeng et al., 2000).

Oral submucous fibrosis is a prototype of pathological fibrosis sharing characteristics in common with other organ involvements where deposition of collagen is taking place primarily in the oral submucosa (Shiau and Kwan, 1979). It has been found that alkaloid (areca-nut) exposure of buccal mucosal fibroblasts may result in the accumulation of collagen (Harvey et al., 1986). A reduced degradation of the alpha 1(1) collagen trimer synthesized by OSF fibroblasts may induce the alteration of the ratio of alpha 1(1) : alpha 2 (1) chains (Kuo et al., 1995). Collagenase activity has been found to be reduced in OSF than in normal oral mucosa (Shieh and Yang, 1992). This evidence implies that OSF may be considered a collagen-metabolic disorder resulting from alkaloid exposure and individual variation in collagen metabolism.

\section{Role of Heat shock proteins (HSP) in pathogenesis of OSF}

HSP47, is a $47 \mathrm{kDa}$ collagen-binding heat shock protein (HSP), which belongs to the serine protease inhibitor (serpin) superfamily containing a serpin signature sequence (17). HSP47 is known as a molecular chaperone that is specifically involved in the processing and quality control of collagen molecules Shung et al., (2008) first found that arecoline is capable of stimulating HSP47 mRNA expression in human BMFs. HSP47 plays an important role in the synthesis, processing, and assembly of various collagens. Previously, their data have shown that arecoline could enhance collagen synthesis in human gingival fibroblasts (Chang et al., 1999). Consistently, study by Shung Fa, ound that HSP47 mRNA was upregulated by arecoline in human BMFs. Thus, authors propose that the accumulation of collagen in oral mucosal connective tissue may be caused by a simultaneous effect on HSP47 by areca quid chewing.

J Cancer Sci Ther

Volume 1(2) : 072-077 (2009) - 074 


\section{Role of basic fibrobalstic growth factor (bFGF) in patho- genesis of OSF}

The FGFs, which often interacts synergistically with other growth factors, may possibly have an effect on extracellular matrix (ECM) deposition. The biological activity of basic fibroblast growth factor (bFGF) in fibroblast, the surrounding matrix and its role as a mediator in the pathogenic process of OSF is of paramount importance, as a better understanding of the cytokines and cytokine networks involved in the early stages of fibrosis could widen newer therapeutic strategies and better the treatment options for OSF.

The bFGF may either directly stimulate endothelial cell proliferation or facilitate VEGF-endothelial cell interaction through the modulation of endothelial cell integrin or VEGF-receptor expression (Salcedo et al., 1999). The increased bFGF expressivity in endothelial cells along with fibroblasts in OSF cases was an important observation, as bFGF potentiates leukocyte recruitment to inflammation by enhancing endothelial adhesion molecule expression (Zittermann and Issekutz, 2006). It has also been demonstrated that endothelial cell derived IL-1 and bFGF modulate fibroblast properties independently, which supports the hypothesis that altered endothelial cell-fibroblast communication may be involved in the pathogenesis of fibrosis (Wojas-Pelc and Lipko-Godlewska, 2005). The endothelial cell and fibroblast dysfunction may be linked through the paracrine activity of soluble endothelial cell products (Denton et al., 1997). Mast cells which are found in the early stages of OSF are indicated to be a primary source of heparin and may serve as a significant source for heparin binding growth factor, the bFGF, in disease processes (Qu et al., 1995). The altered stromal distribution of bFGF in OSF could be because of lower stromal cell concentration and aberrant extracellular deposition of cytokine (Yoon et al., 2001). Another possible explanation for the observed abnormality in OSF may be because of a defect in either ligand production or cell surface deposition of the cytokine. Therefore, a potential defect in the extracellular binding of bFGF might involve a different set of bFGF binding molecules including heparin-like glycosaminoglycans.

Recently, the direct effect of (basic fibroblasts growth factor) bFGF-1 and TGF- $\beta$, on fibroblast proliferation and collagen synthesis using cultured oral fibroblasts have shown opposing effects on growth, differentiation and extracellular matrix accumulation. While bFGF was autorepressive and catabolic, TGF$\mathrm{b}$ has shown to be autoinductive and anabolic, thus representing a part of feedback mechanism controlling stromal growth. However, when bFGF and TGF $\beta$, were associated, the anabolic effects prevailed (Silverio-Ruiz et al., 2007). Contrary to this effect, bFGF was found to be the most potent growth factor in increasing proliferation, glycosaminoglycans synthesis and promoting collagen synthesis in TMJ disk cells (Detamore and Athanasiou, 2004). Additional studies to test the effect of bFGF and TGF-b alone and in combination on cultured fibroblasts from OSF tissues may prove beneficial, as these studies may provide a greater insight into its pathogenesis and offer novel options for therapeutic intervention.

\section{Precancerous nature and malignant transformation}

The precancerous nature of OSF was first described by Paymaster in 1956 when he observed slow growing squamous cell carcinoma (SCC) in one third of the patients with the disease (Paymaster, 1956). This was confirmed by various groups and Pindborg in 1972 put forward five criteria to prove that the disease is precancerous (Pindborg et al., 1984). They included, high occurrence of OSF in oral cancer patients, higher incidence of SCC in patients with OSF, histological diagnosis of cancer without any clinical suspicion in OSF, high frequency of epithelial dysplasia and higher prevalence of leukoplakia among OSF cases (Pindborg et al., 1967). Malignant transformation rate of OSF was found to be in the range of 7-13\%. According to long term follow-up studies a transformation rate of $7.6 \%$ over a period of 17 years was reported (Murti et al., 1985). Authors hypothesize that dense fibrosis and less vascularity of the corium, in the presence of an altered cytokine activity creates a unique environment for carcinogens from both tobacco and areca nut to act on the epithelium. It could be assumed that carcinogens from areca nut accumulate over a long period of time either on or immediately below the epithelium allowing the carcinogens to act for a longer duration before it diffuses into deeper tissues. Less vascularity may deny the quick absorption of carcinogens into the systemic circulation (Tilakaratne et al., 2006). An observation which is still intriguing in the pathogenesis of OSF and its subsequent malignant transformation is the often reported cases of carcinomas, rather than sarcomas associated with the disease. To the best of our knowledge no case of sarcomatous transformation had been reported of this disease, even though it is of stromal origin. The concept of a link between stromal cell maturation and adjacent epithelial proliferation was introduced more than 20 years ago (Cunha et al., 1980) and has gained support since. This interaction is mediated by soluble paracrine signals and ECM components secreted from developing mesenchyme that induce the adjacent epithelia to proliferate rapidly. A new balance of mesenchymal-epithelial crosslink is reached during tissue maturation (Bhowmick et al., 2004). During tumorigenesis, however, the prevailing model suggests a process whereby pre-cancerous epithelial cells acquire multiple genetic mutations and the associated stroma becomes "activated" commonly expressing myofibroblastic markers (Ronnov-Jessen et al., 1996). The characteristics of an activated carcinoma-associated fibroblast are not completely understood. Such cells are presumed to express $\alpha$ smooth muscle actin, ECM proteins, and growth factors that act in an autocrine and paracrine fashion to potentiate and support the survival of a tumor (Bhowmick et al., 2004).

\section{Treatment}

The list of other treatment modalities (Table 2) is extensive and includes use of micronutrients and minerals, carbon dioxide laser, pentoxifylline, lycopene, interferon gamma, turmeric, hyalase, chymotrypsin and collagenase. As fibrosis cannot be reversed, when mouth opening is severely limited surgical interventions, such as myotomy, coronoidectomy and excision of fibrotic bands, are required. Reconstruction using such techniques as buccal pad flap, superficial temporal flap and forearm flap, can also be performed. Alternative procedures, such asinsertion of an oral stent, physiotherapy, local heat therapy, mouth exercises using acrylic carrots and ice cream sticks, have been tried with variable rates of success. In most cases, depending on the stage of disease and extent of oral involvement, therapy consisting of a combination of the above-mentioned drugs and surgery might be useful.

J Cancer Sci Ther
Volume 1(2) : 072-077 (2009) - 075 


\section{Journal of Cancer Science \& Therapy - Open Access JCST/Vol.1 Issue 2}

\begin{tabular}{|c|c|}
\hline Treatment & Treatment Details \\
\hline $\begin{array}{l}\text { Micronutrients } \\
\text { and minerals }\end{array}$ & $\begin{array}{l}\text { Vitamin A, B complex, C, D } \\
\text { and E, iron, copper, calcium, } \\
\text { zinc, magnesium, selenium } \\
\text { and others }\end{array}$ \\
\hline Lycopene & $68 \mathrm{mg}$ twice a day for 2 months \\
\hline Pentoxyfilline & $\begin{array}{l}400 \mathrm{mg} 3 \text { times a day for } \\
7 \text { months }\end{array}$ \\
\hline Interferon gamma & $\begin{array}{l}\text { Intralesional injection of } \\
\text { interferon gamma }(0.01- \\
10.0 \mathrm{U} / \mathrm{mL}) 3 \text { times a day for } \\
6 \text { months }\end{array}$ \\
\hline Steroids & $\begin{array}{l}\text { Submucosal injections twice } \\
\text { a week in multiple sites for } \\
3 \text { months }\end{array}$ \\
\hline Steroids & Topical for 3 months \\
\hline $\begin{array}{l}\text { Hyalase }+ \\
\text { dexamethasone }\end{array}$ & - \\
\hline Placental extracts & $\begin{array}{l}\text { Turmeric30 Alcoholic extracts of } \\
\text { turmeric } \\
(3 \mathrm{~g}) \text {, turmeric oil }(600 \mathrm{mg}), \\
\text { turmeric oleoresin }(600 \mathrm{mg}) \\
\text { daily for } 3 \text { months }\end{array}$ \\
\hline $\begin{array}{l}\text { Chymotripsin, } \\
\text { hyaluronidase and } \\
\text { dexamethasone31 }\end{array}$ & $\begin{array}{l}\text { Chymotripsin }(5000 \mathrm{IU}) \text {, } \\
\text { hyaluronidase }(1500 \mathrm{IU}) \text { and } \\
\text { dexamethasone }(4 \mathrm{mg}) \\
\text { twice weekly submucosal } \\
\text { injections for } 10 \text { weeks }\end{array}$ \\
\hline
\end{tabular}

Table 2: Treatment modality for OSF (Auluck et al., 2008).

\section{Conclusion}

In summary, the available literature indicates that the main aetiological factors for OSF are the constituents of areca nut, mainly arecoline, whilst tannin may have a synergistic role. These chemicals appear to interfere with the molecular processes of deposition and/or degradation of extracellular matrix molecules such as collagen, causing imbalance in the normal process. The most likely events that take place with regards to the above imbalance may be reduced phagocytosis of collagen by fibroblasts, up or down regulation of key enzymes such as lysyl oxidase, matrix metalloproteinases and tissue inhibitors of matrix metalloproteinases. The process may also be influenced by increased secretion of inflammatory cytokines, growth factors and decreased production of anti-fibrotic cytokines. Although the above mechanisms may explain the induction, maintenance and progression of fibrosis in OSF, further research is required in order to identify the mechanism leading to carcinogenesis in this fibrotic oral mucosa. Nutritional deficiencies may not play a primary role but it could synergies the symptomotology by contributing to epithelial atrophy. Although the involvement of HLA and genetic predisposition has been reported, specific haplotypes have not been determined. The individual mechanisms operating at various stages of the disease-initial, intermediate and advanced-need further study in order to propose appropriate therapeutic interventions.

\section{References}

1. Auluck A, Rosin MP, Zhang L, Sumanth KN (2008) Oral Submucous fibrosis, a clinically benign but potentially malignant disease: Report of 3 Cases and Review of the Literature. J Can Dent Assoc 74: 735-740. » CrossRef » PubMed » Google Scholar

J Cancer Sci Ther
2. Bhowmick NA, Chytil A, Plieth D, Gorska AE, Dumont N, et al. (2004) TGF- $\{$ beta $\}$ Signaling in Fibroblasts Modulates the Oncogenic Potential of Adjacent Epithelia. Science 303: 848-51. » CrossRef » PubMed » Google Scholar

3. Caniff JP, Harvey W (1981) The etiology of oral submucous fibrosis: the stimulation of collagen synthesis by extracts of areca nut. Int J Oral Surg 10: 163-7. » PubMed » Google Scholar

4. Chang YC, Tai KW, Lii CK, Chou LS, Chou MY (1999) Cytopathologic effects of arecoline on human gingival fibroblasts in vitro. Clin Oral Invest 3: 25-9. » CrossRef » PubMed » Google Scholar

5. Chen A, Zheng S (2008) Curumin inhibits connective tissue growth factor gene expression in activated hepatic stellate cells in vitro by blocking NFkappa B and ERK signaling. Br J Pharmacol 153: 557-67. »CrossRef » PubMed

6. Chiang CP, Hsieh RP, Chen TH, Chang YF, Liu BY (2002) High incidence of autoantibodies in Taiwanese patients with oral submucous fibrosis. J Oral Pathol Med 31: 402-9. » CrossRef » PubMed » Google Scholar

7. Cunha GR, Reese BA, Sekkingstad M (1980) Induction of nuclear androgen-binding sites in epithelium of the embryonic urinary bladder by mesenchyme of the urogenital sinus of embryonic mice. Endocrinology 107: 176770. » CrossRef » PubMed » Google Scholar

8. Denton CP, Xu S, Black CM, Pearson JD (1997) Scleroderma fibroblasts show increased responsiveness to endothelial cell-derived IL-1 and bFGF. J Invest Dermatol 108: 269-74. » PubMed » Google Scholar

9. Detamore MS, Athanasiou KA (2004) Effects of growth factors on temporomandibular joint disc cells. Arch Oral Biol 49: 577-83. »CrossRef » PubMed » Google Scholar

10. Goel A, Kunnumakkara AB, Aggarwal BB (2008) Curcumin as "Curecumin": from kitchen to clinic. Biochem Pharmacol 75: 787-809. »CrossRef » PubMed » Google Scholar

11. Gupta PC, Sinor PN, Bhonsle RB, Pawar VS, Mehta HC (1998) Oral submucous fibrosis in India: a new epidemic? Natl Med J India 11: 113-6. » PubMed » Google Scholar

12. Gupta PC, Ray CS (2004) Epidemiology of Betel quid usage. Ann Acad Med Singapore 33: 31-6. » CrossRef » PubMed » Google Scholar

13. Haque MF, Meghji S, Khitab U, Harris M (2000) Oral submucous fibrosis patients have altered levels of cytokine production. J Oral Pathol Med 29: 123-8. » CrossRef » PubMed » Google Scholar

14. Harvey W, Scutt A, Meghji S, Canniff JP (1986) Stimulation of human buccal mucosa fibroblasts in vitro by betel-nut alkaloids. Arch Oral Biol 31: 45-9. » PubMed » Google Scholar

15. Hazare VK, Goel RR, Gupta PC (1998) Oral submucous fibrosis, areca nut and pan masala use: a case-control study. Natl Med J India 11: 299. » PubMed » Google Scholar

16. Hoffmann D, Brunnemann KD, Prokopczyk B, Djordjevic MV (1994) Tobacco specific N-nitrosamines and areca nut derived N-nitrosamines: chemistry, biochemistry, carcinogenicity and relevance to humans. J Toxicol Env Health 41: 1-52. » PubMed

17.IARC Anonymous (1985) Tobacco habits other than smoking: betel quid and areca nut chewing and some related nitrosamines. IARC Monogr Eval Carcinog Risk Chem Hum 37: 141-200.

18. Jeng JH, Ho YS, Chan CP, Wang YJ, Hahn LJ (2000) Areca nut extract upregulates prostagladin production, cyclooxygenase- $2 \mathrm{mRNA}$ and protein expression of human oral keratinocytes. Carcinogenesis 21: 1365-70. $»$ CrossRef » PubMed » Google Scholar

19. Kagen HM, Trackenman PC (1991) Properties and function of lysyl oxidase. Am J Respir Cell Mol Biol 5: 206-10. » PubMed » Google Scholar

20. Kuo MY, Chen HM, Hahn LJ, Hsieh CC, Chiang CP (1995) Collagen biosynthesis in human oral submucous fibrosis fibroblast cultures. J Dent Res 74: 1783-8. » CrossRef » PubMed » Google Scholar

21. Ma RH, Tsai CC, Shieh TY (1995) Increased lysyl oxidase activity in fibroblasts cultured from oral submucous fibrosis associated with betel nut chewing in Taiwan. J Oral Pathol Med 24: 407-12.» PubMed » Google Scholar

Volume 1(2) : 072-077 (2009) - 076 
Citation: Dyavanagoudar SN (2009) Oral Submucous Fibrosis: Review on Etiopathogenesis. J Cancer Sci Ther 1: 072-077. doi:10.4172/ 1948-5956.1000011

22. Murti PR, Bhonsle RB, Gupta PC, Daftary DK, Pindborg JJ (1995) Etiology of oral submucous fibrosis with special reference to the role of areca nut chewing. J Oral Pathol Med 24: 145-52.» PubMed » Google Scholar

23. Murti PR, Bhonsle RB, Pindborg JJ, Daftary DK, Gupta PC, et al. (1985) Malignant transformation rates in oral submucous fibrosis over a 17 year period. Community Dent Oral Epidemiol 13: 340-1. » Google Scholar

24. Nathan C, Sporn M (1991) Cytokines in context. J Cell Biol 113: 981-6. $»$ Google Scholar

25. Paymaster JC (1956) Cancer of the buccal mucosa; A clinical study of 650 patients. Cancer 9: 431-5. » PubMed » Google Scholar

26. Pindborg JJ, Murti PR, Bhonsle RB, Gupta PC, Daftary DK, et al. (1984) Oral submucous fibrosis as a precancerous condition. Scand J Dent Res 92: 224-9. » PubMed » Google Scholar

27. Pindborg JJ, Poulsen E, Zachariah J (1967) Oral epithelial changes in thirty Indians with oral cancer and oral submucous fibrosis. Cancer 20: 1141-6. $»$ PubMed » Google Scholar

28. Qu Z, Liebler JM, Powers MR, Galey T, Ahmadi T, et al. (1995) Mast cells are the major source of basic fibroblastic growth factor in chronic inflammation and cutaneous hemangiomas. Am J of Pathol 147: 564-73.» Google Scholar

29. Rajalalitha P, Vali S (2005) Molecular pathogenesis of oral submucous fibrosis-collagen metabolic disorder. J Oral Pathol Med 34: 321-8. » Google Scholar

30. Rajendran R, Kumari KR, Kumar AS (2003) Liver ultrasound and faecal copper estimation in oral submucous fibrosis. Ind J Dent Res 14: 13-21. » PubMed » Google Scholar

31. Roberts AB, Flanders KC, Kondaiah P, Thompson NL, Van ObberghenSchilling E, et al. (1988) Transforming growth factor beta: biochemistry and roles in embryogenesis, tissue repair and remodeling, and carcinogenesis. Recent Prog Horm Res 44: 157-97. » PubMed » Google Scholar

32. Roberts AB, Heine UI, Flanders KC, Sporn MB (1990) Transforming growth factor-beta. Major role in regulation of extracellular matrix. Ann N Y Acad Sci 580: 225-32. » CrossRef » PubMed » Google Scholar

33. Rønnov-Jessen L, Petersen OW, Bissell MJ (1996) Cellular changes involved in conversion of normal to malignant breast: importance of the stromal reaction. Physiol Rev 76: 69-125. » CrossRef » PubMed » Google Scholar

34. Salcedo R, Wasserman K, Young HA, Grimm MC, Howard OM, et al. (1999) Vascular endothelial growth factor and basic fibroblast growth factor induce expression of CXCR4 on human endothelial cells: in vivo neovascularization induced by stromal-derived factor-1alpha. Am J Pathol 154: 1125-35. »CrossRef » PubMed

35. Schwartz J (1952) Atrophia idiopathica tropica mucosa oris. In:Proceedings of the 11th International Dental Congress in London.

36. Shiau YY, Kwan HW (1979) Submucous fibrosis in Taiwan. Oral Surg Oral Med Oral Pathol. 47: 453-7. » Google Scholar

37. Shieh TY, Yang JF (1992) Collagenase activity in oral submucous fibrosis. Proc Natl Sci Counc Repub China B. 16: 106-10. » PubMed » Google Scholar
38. Yang SF, Tsai CH, Chang YC (2008) The upregulation of heat shock protein 47 expression inhuman buccal fibroblasts stimulated with arecoline. $\mathrm{J}$ Oral Pathol Med 37: 206-210. » CrossRef » PubMed » Google Scholar

39. Silverio-Ruiz KG, Martinez AE, Garlet GP, Barbosa CF, Silva JS, et al. (2007) Opposite effects of bFGF and TGF-beta on collagen metabolism by human periodontal ligament fibroblasts. Cytokine 39: 130-7. » CrossRef » PubMed » Google Scholar

40. Sinor PN, Gupta PC, Murti PR, Bhonsle RB, Daftary DK, et al. (1990) A case-controlstudy of oral submucous fibrosis with special reference to the etiologic role of areca nut. J Oral Pathol Med 19: 94-8. » PubMed » Google Scholar

41. Tilakaratne WM, Klinikowski MF, Saku T, Peters TJ, Warnakulasuriya S (2006) Oral submucous fibrosis: Review on etiology and pathogenesis. Oral oncology 42: 561-68. » CrossRef » PubMed » Google Scholar

42. Trivedy C, Baldwin D, Warnakulasuriya S, Johnson N, Peters T (1997) Copper content in areca catechu products and oral submucous fibrosis. Lancet 340: 1447. » CrossRef » PubMed » Google Scholar

43. Trivedy C, Meghji S, Warnakulasuriya KA, Johnson NW, Harris M (2001) Copper stimulates human oral fibroblasts in vitro: a role in the pathogenesis of oral submucous fibrosis. J Oral Pathol Med 30: 465-70. » CrossRef » PubMed » Google Scholar

44. Trivedy CR, Warnakulasuriya KA, Peters TJ, Senkus R, Hazare VK, et al. (2000) Raised tissue copper levels in oral submucous fibrosis. J Oral Pathol Med 29: 241-8. » CrossRef » PubMed » Google Scholar

45. Trivedy C, Warnakulasuriya KA, Hazare VK, Tavassoli M, Sommer P, et al. (1999) The upregulation of lysyl oxidase in oral submucous fibrosis and squamous cell carcinoma. J OralMed Pathol 28: 246-51. » PubMed » Google Scholar

46. Wojas-Pelc A, Lipko-Godlewska S (2005) Pathogenesis of skin scleroderma - literature review. Przegl Lek 62: 310-3. » PubMed » Google Scholar

47. Yi-Ting D, Chen HM, Cheng SJ, Chiang CP, Kuo MY (2009) Arecolinestimulated connective tissue growth factor production in human buccal mucosal fibroblasts: Modulation by curcumin. Oral oncology 45: 99-105. » CrossRef » PubMed » Google Scholar

48. Yoon SY, Tefferi A, Li CY (2001) Bone marrow stromal cell distribution of basic fibroblast growth factor in chronic myeloid disorders. Haematologica 86: 52-7. » CrossRef » PubMed » Google Scholar

49.Zain RB, Ikeda N, Gupta PC, Warnakulasuriya S, van Wyk CW, et al. (1999) Oral mucosal lesions associated with betel quid, areca nut, tobacco chewing habits. Consensus from a work shop held in Kuala Lumpur, Malaysia. J Oral Pathol Med 28: 1-4. » PubMed » Google Scholar

50.Zittermann SI, Issekutz AC (2006) Basic fibroblast growth factor (bFGF, FGF-2) potentiates leukocyte recruitment to inflammation by enhancing endothelial adhesion molecule expression. Am J Pathol 168: 835-46. »CrossRef » PubMed » Google Scholar 